\title{
A MERCURY POROSIMETRY STUDY OF THE EVOLUTION OF POROSITY IN PORTLAND
}

\section{CEMENT}

\section{NOVEMBER 1969 - NUMBER 31}

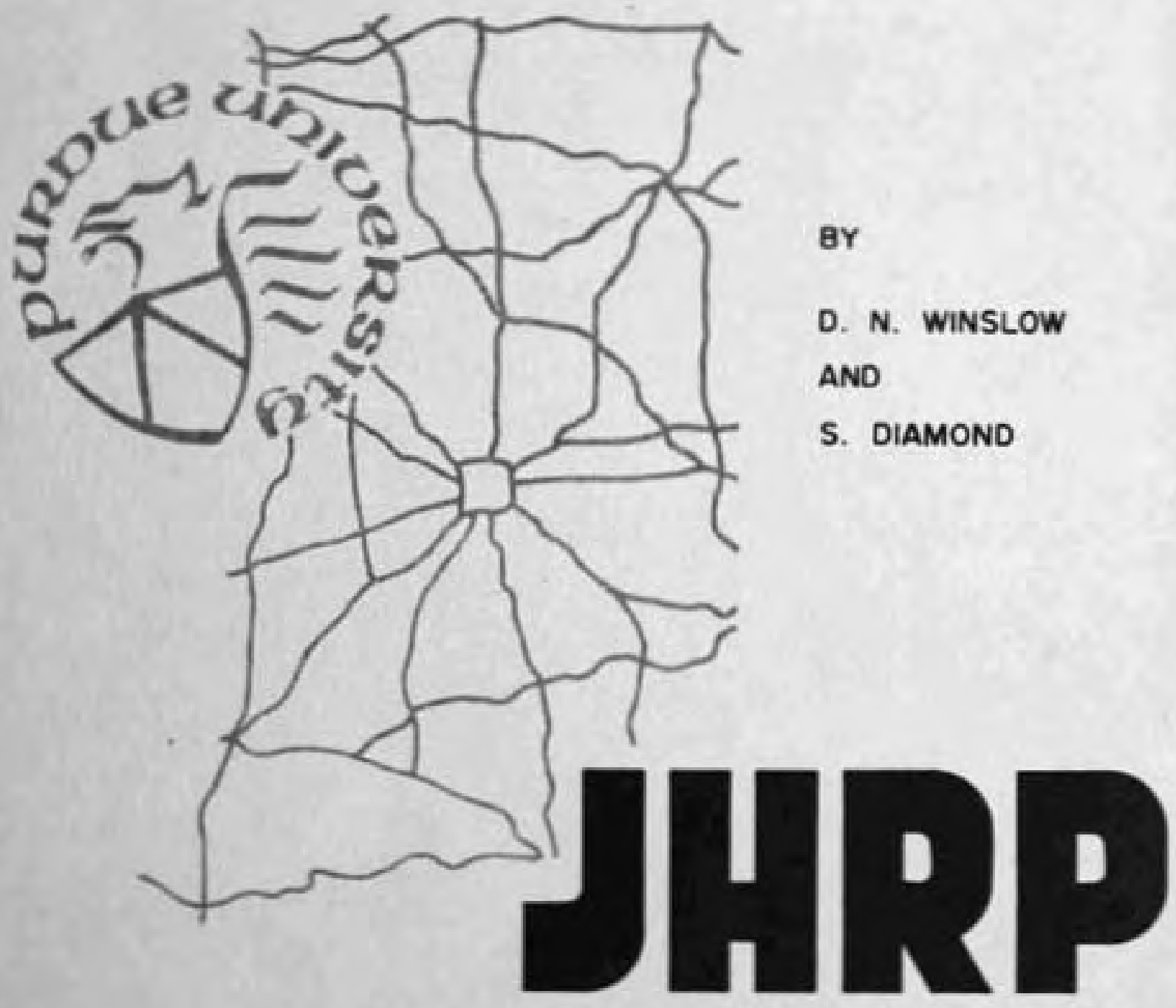

JOINT HIGHWAY RESEARCH PROSECT PukDUe unvenstry aND 
Digitized by the Internet Archive in 2011 with funding from

LYRASIS members and Sloan Foundation; Indiana Department of Transportation

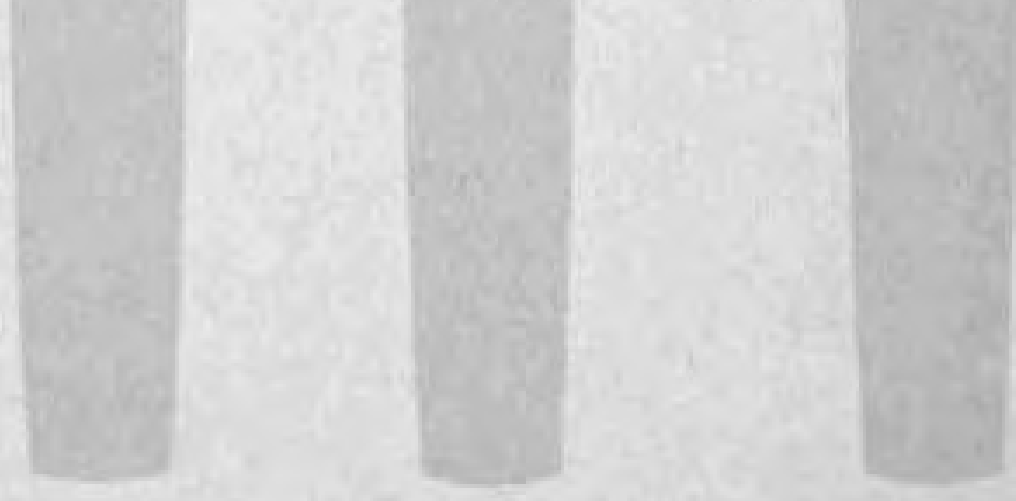

http://www.archive.org/details/mercuryporosimet00wind 
A Mercury Porosimetry Study of the Evolution of Porosity in Portland Cenent

To: J. F. Melaughlin, Director Joint Highway Research Project

From: 甘. L. M1chael, Associate DIrector Joint Highway Research Project
4 November 1969

Project: C-36-61E

F1le: $\quad 5-14-5$

The attached technical paper, "A Mercury Porosimetry Study of the Evolution of Porosity in Portland Cement" by D. N. Winslow and S. Diamond 18 derived from the Final Report on Phase I of the HPR Part II research project "Fundamental Studies in Portland Cement Concrete".

The peper reviews the mercury intrusion technlque for measurement of pore size distribution in porous media, preaents experinental results on such measurements in hydrated portland cement paste of various ages, and interprets the results in the forn of a consistent picture of the development of microstructure as cement paste hydrates over a period of tine.

The paper has been presented orally at the July 1969 meeting of the ASTM by Prof. Dlamond. It is now presented to the Board for approval and for trenemission to BPR and ISHC for review and approval for publication. It is proposed for publication by ASTM in the Journal of Materials.

Respectully subuitted, HanredL Michael/wrD

Harold L. Michael Assoclate D1rector

HLM: pm

ec: JHRP Board 


\section{Technical Pub1ication}

\section{A Mercury Potosimetry Study of the Evolution \\ of Porosity in Portland Cement \\ by \\ D. N. Winslov \\ and \\ 5. Dianond}

Jolnt Highvay Research Profect

$$
\begin{aligned}
\text { Project: } & C-36-61 \mathrm{E} \\
\text { F1le: } & 5-14-5
\end{aligned}
$$

Prepared as Part of an Investigation

Conducted by

Jo1nt Highway Research Project

Engineering Experinent Station

Purdue University

In cooperation with the

Indiana State Highway Comalasion

and the

U.S. Department of Transportation

Federal Highway Administration Bureau of Public Roads

The opinions, findings and conclusions expressed in this publication are those of the authors and not necesearlily those of the Bureau of Public Roads.

Not Relensed for Publication

Not Reviewed By
Indiana State Highway Comission
or the
Bureau of Public Roads

Purdue University

Lafayette, Indiana

18 Decesber 1968 


\section{ABSTRACT}

The pore-size distribution of two hydration series of cement pastes prepared at water:cement ratios of 0.4 and 0.6 was deternined as a function of age using mercury porosimetry. The contact angle of mercury on thoroughly dried paste vas measured as $117^{\circ}$; for "p"-dr1ed paste it was found to be $130^{\circ}$. It was found that much of the pore space present at all ages occurred in pores between $0.1 \mu$ and $0.01 \mu$; that 1s, in between the conventional notions of "capillary" and "ge1" pore dlameters. It was further observed that pore volume left unintruded by mercury at 15,000 psi was significantly less than the 28 percent by volume that should be present In mature pastes according to current notions of the nature of cement gel. On the basis of these observations and direct examination of fracture surfaces of cement paste it was concluded that most of the space present is nefther conventional "cap1llary" nor conventional "gel" space but merely space between fine individual particles of cenent hydration products.

\section{Key Words}

Cement paste, mercury porosimetry, capillary pores, gel pores, concrete, Portland cement, cement hydration, pore-size distribution, contact angle 


\section{INTRODUCTIOR}

Notlons of the mferostructure of portland cement paste derfved wosty from the poatulatlons of T. C. Pouers and co-workers as extended by various workers are coning increasingly into queation as data based on nev Investigative techniques are reported. One of the nost fundasental of these notions is that in hydrating ceeent paste two distinct kinds of pores vere presuned to be present: "cap111ery" pores which represent remnanta of intergranular apace left unf1lled by the varfous products of cement hydratioa (1ine, celefur silicate hydrate gel, hydrated calclus aufoaluminates, etc.), and "ge1" pores. The latter were presumed to be a choracteristic festure inherent in the nature of hydrated cement peste, occupylog approximately 28 percent of 1 ts volume, and according to Potrers' 1960 estinate (1), having a width of the order of $18 \mathrm{~A}$. Powers also suggests in the sane review paper that cap11laxy pores are "generally orders of magnitude larger than gel pores, even In thature paste.

Direct examination of cenent paste by scanning electron ulcroscopy $(2,3,4)$ suggests that cement paste 1s, in fact, largely a particulate system conposed of prianry particles of various ahapes and sizes, but with characterlstic dimensions of che order of 0.1 micron to a fes mierons. Examination of fractura surfaces at high magnification also discloses that spaces ('porea') of the order of a sall fraction of a aicron are present between the 
primary particles of cesent hydration products. F1gure 1 shows a typical example. In addition, often a portion of the hydrated paste 1s seen to consist of reticular, spongy areas with visible holes or discontinuttes of the order of 0.1 aferon or less in dianater. An exampla of this is shown in Figure 2.

In consequence of these observations, it would seen that a nore realistic 1dea of the pore structure of hydrated cenent parte needs to include recogaition of such pores intermediate in sfre bacween conventfonal sotions of ceplliary and gel pores. Turther, if a significant content of such interaedlate pores occurs in nature paste, the volune of gel pores present alght be less thas the 28 percent conventionelly est-lmated, perhape significently leae.

The prevent vork represents an attenpt to explore and evaluate the content of pores of various size ranged in a serles of portland coment pestes of ineressing age prepered from a single cement. The focus of the problen is to secure a valid pore-aise distribution curve, not only for a given paste, but for pastes representing the whole process of cenent hydracton. In this way some notion of the origin and changes undergone by the wicrostructutal featurea of the paste might be developed.

Tho mathod chosen was that of mercury porostmetry. This procedure, while sufferlng from certafn arbitrary asumptions that vil be difcusaed later, represents the most nearly direct assay of pore aises avaslable at the present tipe. Alternate techniques, such as those involving capillacy condensation, favolve assuaptions 
that in fact are quite difficult to fulfil in cement paste studies.

\section{HYDRATION OP CEMEMT PASTE}

The cement used throughout vas a comercial Type I cenent of blaine fineness of $3380 \mathrm{~cm}^{2} / \mathrm{g}$ with a composition of $\mathrm{S1}$ percent $\mathrm{C}_{3} \mathrm{~S}$, 24 percent $C_{2} s, 11$ percent $C_{3} A$ and 6 percent $C_{4} A P$ caleulated according to the Bogue method. Analysis diselosed a gypsum content of 4.1 perceat as $\mathrm{CaSO}_{4}$, a free 11 he content of 0.72 perceat and a total alkali content of 0.38 percent as $\mathrm{Ha}_{2} \mathrm{O}$.

A11 nixing and curing operations vere carried out at roon tenperature, approximately $24^{\circ} \mathrm{C}$, in an air-conditioned laboratory.

Mixing vas done in vacuo in a specially ande cylindrical plastic mixer, which weo loaded with several steel rods and flint balls and a standard charge of $1000 \mathrm{~g}$ of cement, and then evacuated. Water was added through a valve without breaking the vacuum, and the mixer then alternately rolled on an electric roller at $100 \mathrm{rpm}$ and shaken by hand, according to a preset schedule for a total of 25 minutes. The vacuun vas then released and the paste placed fato $12-\mathrm{ml}$ polypropylene test tubes by rodding in three layors on a vibrating table. A tight fitting stopper was then positioned wo that no free volune was left above the paste and vibration continued with frequent reversal of top and botton according to a preset schedule. The sanples were then atored (stoppered) in a fog roon for 24 hours, denolded directly Into saturated limevater, and alloved to hydrate continuousiy unt 11 the desired age vas attained. 
Checks of density confirmed essentialiy complete uniforalty within each cylinder except for the top and bottom ends; in practice, specimens for analysis vere taken only from the middle one third of each cylinder and the outer two thirda diecarded.

Two aeries of pastes vere ande, one at a vatericeatent ratio or 0.6, the other at 0.4. Approxirately 320 Individual cylinders vere prepared for this work, and pore-size distributlons were rua on approxinately 30 of then.

Considerable prelintnary work vas done to determine the nost spproprlate drying technique, since it is necensary to begin a nercury porosineter run with all of the sample pores vacant. As the result of a number of cosparisons of the rasults of varlous standard nethode of drying ("P-drylng" over a nixture of aagnestum perchiorate hydrates, "D-drylng" over a dry ice trap, and oven drylng at $105^{\circ} \mathrm{c}$ ) the oven-drying procedure was selected as the standard proccdure. A discusston of theae experinental comparisons 1s given subsequentiy in chis paper. All samples tested for poregize distribution were oven dried, broken Into pleces of the order of one graa in vesght, and then tested in the bulk condition, 1. e. not ground to a powder.

\section{DETATLS OF THS DEIBRMTATION OF PORE-SIZE DISTRIBUTIOS BY MERCURY POROSTERRY}

Theory

$A$ non-vetting Ifquid (1.e. one foraing a contact angle vith a given sol1d greater then $90^{\circ}$ ) will Intrude open pores of the 
solid only under applied pressure. The pressure required is a function of the contact angle, the aurface energy of the 11quid, and the geosetry of the pores. Por the case of cylindrical pores the relation given by Washburn (5) is:

$$
P=\frac{-4 \gamma^{-} \cos \theta}{d}
$$

where: $\quad$ P - pressure required to intrude pore

d - dianeter of intruded pore

$Y=$ surface energy of the liquid

0 - contact angle becveen liguid and pore vall

Hercury is almot always used ss the liquid as it has s nubber of practical advantages lncluding low vapor preseure, relative inertnees in terms of chemical resetivity, and the fact that it is normally non-jetting for most kinds of surfaces.

The practical upper 11mit of pore diameters neaeurable by mercury porosinetry ay be extended to about 1000 microns or more by approprlate techniques; the lower limit is usually set by the pressuring cepac1ty of the instrumeat although conelderable uncertalnty accompanies the use of very high pressures corresponding to pores of only a few molecular diaseters. In the present work the upper 1feit of neasurement vas taken to 200 wierons, although for mot pastes very little pore space vas found for diabaters larger than 10 merons. The lover diazetez 11 mt vas set by the pressuring capactty of the 1astrument used, approxinately 15,000 pal, and correaponds to about 82 A (0.0032 merons) for oven drfed paste. 
There are certain 1 inftations inherent in the mercury poreaize distribution cechnique. At the outset of a mercury intrusion determination the sample is surrounded by mercury; as pressuring procedes, wercury tlows from the surface of the sample tovards its center through whatever pores are avallable to $1 \mathrm{t}$. If the path mercury aust follov to reach a particular internal pore is saller in diaseter than the internal pore 1tself, that pore w11 be intruded only after sufficieat pressure 1s applied to intrude the aarrower pathuty. Thus, fundasental1y, pores accessible only through restrieted entryways are tallied se part of the diameter elass of the entryways. Slnce entryuays narrover than 82 A could not be 1ntruded in this vork due to the pressure 1imitation, pores of any size connected to the exterior only by entryways narrower than $82 \mathrm{~A}$ vill not have been seasured. P1nally, Isolated pores having no comminication with the exterior of the sample cannot be measured in suy event, regardlees of the pressure used.

\section{Appaxatus}

The instrument used to messure mercury 1ntrusion was an American Instrument Co. unit (Catalogue No. 5-7121) with an operating pressure aaximum of $15,000 \mathrm{psi}$, modified in certain respects. The porosineter consists essentially of a neans of generating pressure to cause intrusion asd a meane of measuring the volue of mercury intruded. We found that the electric notor which drove the presaure generator caused the porosineter to beat up during use, thus affecting the meanureant of the intruded percury. To swold this ve removed the back of the 
Instrument cabinet and relocated the electric motor some distance away. The portion of the equipment used to measure coarse pores (the "f1111ng device") was discarded and replaced by a unt of advanced deaign (U. S. Patent No. 3,438,245, Prado Laboratory, Ine., Cleveland, Ohio). With the nodified unit, the filling device and sazple holder (a dilatoneter-11ke vessel called a penetroneter) are anintained in a horizontal position during all filling and measurement operations, thus pernitting operation substantially free of any pressure applied by the velght of superposed nercury, and extending the upper 11 mit of the range of diameters neasurable froal about 100 alcrons to about 1000 microns.

\section{Corrections For Intrusion Data}

The basic data recorded in mercury porosimetry consist of a series of measurements of Increasing absolute pressures on the mercury and corresponding cumulative volumes of mercury intruded. The apparent volume of intruded mercury that is read at each pressure step must be corrected for several different effects;

1) The residual air remalning in the penetroweter after evacuation is trapped during the Inttial mercury filing etep, and 18 compressed progreasively to increabingly sana11 volumes as presaure increases. The change in voluae due to compression of afr must be subtracted from the gross intruded volume of mercury at each step. Since Initial preasure and volune are known, Boyle's Lav can be used to calculate the required correctlons, which in the preaent work total about $0.001 \mathrm{~cm}^{3}$. 
2) The mercury is being conpressed as the pressure is increased. The required correctioa 1s much less than the absolute loss In voluae of the Ifquid as calculated fron ita cospressibility per se, as the penetroneter containing the aercury $1 \mathrm{a}$ also belng coapressed at the sene tine. Corraction is sade by nessurlog the effect of pressuring in the sase peatcroneter f11led with nercury only, 1.e. without any sanple beins prevent. In the preseat work, the eaxisum corcectloa van of che order of $0.0055 \mathrm{~cm}^{3}$ at $15,000 \mathrm{pet}$.

The coapreselbility of the sasple whoutd also reçuire a mani corrtetion, but no meane of ascertalning the absolute compreculbilicy of the solld part of cenent paste was avaslabie. Handbook valves of the compressibilities of rast ressonably otrong nolids sugest that the volume change froa 0 to 15,000 pol vould in fact be negligible wth roopect to the voluae of nercury intruded inco cement pesta.

It ehould be noted that upon contreasion, mescury hents up. The tetiperature Inorease couses expansion, which tends to utaglc some of the cospression and it is necessary to allow the pexcury to recurp to 1.te orfgtinal tamperature to truly measure the conpresston. In fact, rapld preasuring to 15,000 pat reaulted in oufficient heat to niak rore than 50 percent of the true comproseton and a pause of about $15 \mathrm{gln}$ was found to be required to ellow the marcury to return to fts starting teapersture. This send offect operates durfing actual intrusloa eeasureaents also and must bo taken into account. Keaciuresent of Contact Aagie

In the absence in the avallable Mterature of any spociffe coatact angle neasurements for nereury on cenent paste, a serles 
of measurements vere carried out to determine this quantity. The technique chosen was one which provides the most directly appl1cable measurement for the purpose in hand, and consists of a direct measurement of the pressure required to intrude cylindrical pores of an accurately known dianeter. With the dianeter and pressure known, the factor 4 r cos $\theta$ is calculated directly froe Equation 1 , and assuming the vell-established value for $Y,(6,7)$ of 484 dynes/cm, e follows Imediately. In point of fact, it is not strictly necessary to calculate itself, since the factor $4 \mathrm{y}$ cos 6 required for interpreting the mercury intrusion date is directly avallable from the experibental measuresent.

The measurements vere perforned on a 267 -day old cement paste of the 0.4 vatertcenent rat1o serles. A disk of paste about the size and shape of a dime was cut from the cement pate cylinder using a preciaion lathe and saturated 11mewater as the only lubricant, and a serles of 40 holes were drilled through the disk using a No. 92 twiat dri11, again with 11mewater as the lubricant. Both surfaces of the diak vere examined under an opt1cal microscope to confirm the efreularity of the cross-sections of the drilled cylindrical pores and Individual measuramente of the diameter of each pore were made. The average dameter vas 201.5 microns; not of the diameter measureaents fell between 190 and 210 microns. The disk was then carefully "P-dried" over the appropriate mixture of magnesfun perchlorate bydrates (8), and then subjected to percury intrualon, the pressurlng being carried only slightly beyond that secessary to intrude the drilled pores. The zercury 
spontaneously flowed out of the pores on reducing the pressure, so that repeated weasurements could be made. These were found to be quite reproducible. Subsequently, the same sample vas oven dried at $105^{\circ} \mathrm{C}$ and the intrusion measurements repeated in the oven-dried condition. The pressure and intrusion data are given in Figure 3.

The measurezents Indicate a contact angle of $130^{\circ}$ for the "Pdried" paste, but a contact angle of only $117^{\circ}$ for the oven-dried paste. The relationship betveen pressure and pore diaseter (Equation 1) Involves the cosine of the contact angle; thus, the $13^{\circ}$ difference in contact angle corresponds to a 30 percent drop in the value of the cosine, and hence, In the dianeter Intruded at a given pressure.

It 1o generally considered that "P-dried" pastes do, in fact, contain aose residual surface vater, and the reduction in contact angle on more complete dehydration of the surface on oven drying is In Ine with atmilar changes reported on glass and other substances (9). Thus, the value of $117^{\circ}$ has been used in ealculating pore diameters for all of the cement pastes discussed in this paper, all of which were oven dried prior to mercury intrualon.

\section{Bffects of Sample Drying}

In preliminary studies, companion samples of cenent pastes were dried by each of the three drying procedures in conmon use for cement paste: equilibration over angesium perchlorates ("Pdrylng"), evacuation over a dry-1ce trap ("D-drying") (10), and oven drylag at $105^{\circ} \mathrm{C}$. The methods are given in order of increasing severity of vater removal, the equilibriun vapor pressures befing 
8 ulig (11), and $0.5 \mu$ Hig, respectively, for the first two methods. The pressuring curves for the companion samples had almilar shapes. Use of the measured contact angles for "P"- and oven-dried samples to interpret the data resulted in pore-size distribution curves 11ke those of Figure 4, in which it is seen that the data in the coarse pore region roughly colncide, but that the extent of pore space in diaseter classes smaller than about $1000 \mathrm{~A}$ seens to be a direct function of the rigor of the drying treataent. Data for the "D-dried" condition fall in between the plots for the "P-dried" and the oven-dried pastes, and are more nearly like the forner. An assumed contact angle of $126^{\circ}$ vas used in the absence of a meesured value for this drying condition. Nevertheless, it is quite clear that the very small differences in residual water retained at equilibriun with respect to the different drying treatnents are in some way responsible not only for the changed contact angle but also the relatively large change in apparent mercury pore-6ize distribution in the fine-pore region. That this phenomenon is not associated with microcracking or other itreversible changes accompanying the more rigorous drying procedures is showa by the experimental fect that the change is reverstble. If a sample in dried to veight equilibrium by any of the three techaiques, resaturated, and then redried by another technique, it will exhibit easentially the same pore-size distribution to mercury as $1 f$ it hed orfginally been dried by the second technfque. Data 111ustrating this observation are given in Figure 5. Observation of these pastes by scanning electron meroscopy did not disclose any evidence for 
nicrocracking in the size range concerned, thus conflraing that differential mierocraeking associated with difforences in drying procedure is not the cause of the differing pore-afze distributions. As mentioued earlier, oven drying was finully selected as the standard technique for characterisfing the pore-aise dietributions of the pastes, largely on the assuption that the sore cosplete renoval of vater prfor to the intrugion of sereury probably provides a truer asseasbent of the setusl pore spacen prentat.

\title{
Ponsfble Influence of Carbogation
}

Sose afnisur exposure to the atmosphere balng unavoldable, it vas thought desfrable to check the posstble affects of curboantion on measured pore-nize distributions. Saples vere deliberately exposed to the atmosphere in an intermediate condition of dryness for about three veeks to Insure naximun opportunity for carbonation to take place, and were then drled and teated fo the normal manner. \$o difference was found in the resuleing pore-size distributions as compared with raplicate samples that had only winimum possible exposure to the atmosphere, and 1t was concluded that asposure to the atmosphere did not influence the pore-oize distributione obtained In thin work.

\author{
RESULTS
}

\section{Presentation of Data}

The experimental pore-sine distribution deta in this work are presented in the form of cundative pore-afte distribution curves, 
the pore volume parameter being expressed as $\mathrm{cm}^{3}$ of pore space per oven-dry gram of cement paste. The volumes are accumulated from the largest dlameter pore measured to the smallest, the order in which the pores are phyalcally intruded by the mercury. To retain the normal sense of the logarithelc scale of the abscissa, the cunlation curve procedes froe lover right to upper left.

In present1ng pore-size distrfbution data for linited ranges of pore sizes many authors, particularly those who report results from capillary condensation measurements, prefer to plot the derivative distribution function, $d$ (volume)/d (dianeter), rather than the curulative or Integral volume function. Unfortunately, the derivative presentation $1 \mathrm{~s}$ severely distorted for data covering aeveral orders of magnitude and vastly overemphasizes the apparent importance of the finest pore sizes at the expense of the coarser sizes. Further, the Integral function used here has the distinet advantage that the fraction of pore space between any arbitrary bounds of pore diameters can be assessed at a glance.

Pore measurements were or 1 inally made starting from a diameter of several hundred gterons. but $1 \mathrm{t}$ becane apparent that even the youngest pastes teated showed aegligible Intrusion for diameters greater than 10 microns; the figures thus begin at that diameter. The minimun pore diameter intruded was approximately $82 \mathrm{~A}$.

In genoral, two replicate tests vere conducted on a particular paste, and in sone cases three or four, Repeatab111ty wes excellent, as seen in the figures presented.

Dexree of Hydration, Total Pore Volume, and Pore Volume Intruded

Table 1 presents a surnary of the saples eaployed, in terms of vater:cenent rat 10 and age at cesting. Teste vere conducted 
on 0.4 and 0.6 water:cement ratio pastes hydrated continuously for perlods ranging from one day to approximately eleven months. The percentage of hydration recorded in Table 1 was obtained simply as the ratio of the non-evaporable water (after oven drying) of each paste at the stage concerned to that of a fully hydrated product of the same cesent hydrated for wany moaths in a bal1 =111.

The cotal pore volume present in each paste st che stage concerned was calculated in the following anner: First, the bouyant velght (in vater) of each paste fa the saturated condition vas deternined Imediately on achlevesent of the required age; the paste specinen vas then oven dried, velghed, and the deasity of solld anter calculated. The volume of soldds vas then calculated frow the velght and the density. The bulk volume of the ovendrfed sample was then deteruined by displacesent of mercury, and the difference between bulk volume and sol1d volume vas taken as the total pore space present and this was asseseed as volume per dry gram of the paste. This procedure essumes that the density of water within the pores of the inftally sacurated specinen is the same as that of ordinary water. If, as has been suggested on the basis of Indirect experiments (11), part of the vater that is In the finest pores or most elosely associated with the surface has a higher density, the density of solfd matter w111 be correspondingly overestimated, and the pore space figure wi11 be too 10w. The values calculated for the pastes are, in fact, quite reasonable and one vould not expect this to be a najor effect.

Table 1 also contains, for each paste, the total volue of nercury Intruded Into esch sample. This is in all cases less thra 
the calculated volume of pore space. This is not surprising since pores having nominal diameters smaller than $82 \mathrm{~A}$ and pores penetrable only through necks smaller than 82 A cannot be recorded by the instrunentation employed. What is signifleant is that even for quite mature 0.4 vater:cesent ratio pastes, half or more of the pore space can in fact be intruded, 1.e. consists of pores with poainal dfameters significantly larget than the size range comanly associated with gel pores. This point will be discussed subsequently and 1ta inplications sssessed.

Finally, the pore space calculated to be present, but not intruded by mercury up to the pressuring 11altatioa corresponding to $82 \mathrm{~A}$ diaseter is re-expressed as a percentage of the bulk volume occupied by the systen. This percentage constitutes essentally an upper-bound estinate of the volume fraction of the finest class of pores present, 1.e. those pores that would be assessed as "gel" pores on the basis of the prevailing model. It is an upper-bound estimate because it includes the volume of pores with diameters greater than $82 \mathrm{~A}$ but available to mercury only through constrletions smaller chan this, and also any pores that happen to be completely 1solated. According to the estimates of Powers (12), a fully hydrated paste of water:cement ratio larger than that required to provide roon for complete hydration (1.e. larger than 0.38 ) should have a content of gel pores of 28 percent by voluse. The f1gures in the last column of Table 1 reveal that for the oldest of the paster tested (which are 80 percent and 86 percent hydrated, according to our estimates) there is an upper bound estinate of about 18 pereent by volue in pores not intruded by mercury, 1.e. 
seealngly finer than $82 \mathrm{~A}$ in diameter. This upper bound eatimate is much less than the volume of gel pores that would be present according to Povers. Furthernore, the data do not auggest that further increments of hydration associated with increasing age would lead to any anjor increase in the experimental value.

\section{Characteriatica of the Distribution Curves}

Figure 6 presents the cunulative pore-size distribution curves for the series of 0.6 vater:cenent ratio pastes hydrated for perlods of $1,2,3,5,7,28,59$, and 318 days, respectively. A simllar set of results 1s presented in Figure 7 for the corresponding 0.4 vater: cenent ratio pastes.

The following observations may be ade on exen1ning the general forn and appearance of the curves:

1. The general distribution shifts to the left with locreaoing sge; that 1s, the pores become incresaingly finer with age.

2. The total pore volume intruded decreases with increasing age.

3. All of the curves display an apparent "threshold diameter", above which there is comparatively little Intruston Into the paste, and immediately below wh1ch the greatest portion of the Intrusion comances. The threshold dianeter decreases stendily with age.

4. At any given age both the total Intruded pore space and the threshold dianeter are significantly larger for the 0.6 vater:cenent ratio paste than for the corresponding 0.4 vater:ceaent ratio paste.

5. To a surpriaing degree the overall shapes of the distributlon curves as plotted on a logarithnie disweter seale 
are similar to each other. The only significant exception to this stateneat is the fact that the mature (28 days or older) 0.6 pastes show cumulative distribution curves that are approxinately linear with the log of the diameter, while the correaponding curves for the 0.4 pastes tead to flatten out belou about $300 \mathrm{~A}$.

These general observations are nov discussed in detall. Decrease in Overall Pore Sixe vith Age

This general observation is entirely in accord with ordinary expectation, based efther on the Povers nodel or the sinple observation that the hydration products of cesent are, in general, aigaificantly finer in particle size than the original cenent grains. In consequence, one expects that the residunl spaces preseat decrease as the content of hydration products increasee with increasing age.

F1gure 8 documents this tread quantitatively, by plotting the volume-average pore dianeter as a function of age for each of the two water:cement rat1o ser1es. For alnost all of the pastes the Intruston measured was greater than half the total pore space; thus, the volume-average pore dlameter can be calculated without knowledge of the distribution of remaining fine pore sizes not callied. In each case the dianeter efted is an underestimate to the extent that "Ink bottle" pores Influence the observed distribution. The average diameters for day-old pastes, about 3000 and $1200 \mathrm{~A}$ respectIvely for the 0.6 and 0.4 pastes, drop rapldly to less than $300 \mathrm{~A}$ by a week of hydration; then drop nuch more slowly to valuea of the order of $100 \mathrm{~A}$. 


\section{Decrease of Intruded Pore Volume with Age}

Again, such a result should be expected both on the basis of the Powers nodel of hydration and on the general notion that the hydration products occupy nore volume than that occupled by the cenent grains they replace. Quantitatively, as seen fros Table 1, Intrusion drops from about $0.36 \mathrm{~cm}^{3} / \mathrm{g}$ for 1 day old paste to about $0.19 \mathrm{~cm}^{3} / 8$ for 318 day old paste of 0.6 vater:cenent ratio; the corresponding figures for the 0.4 pastes are 0.27 and $0.10 \mathrm{~cm}^{3} / 8$, respectively.

\section{Threshold Dianeter and Its Sigaificance}

The decrease of the previously defined "threshold dianeter", vith age in docunented in FIgure 9. The pattern of decrease is somevhat sindlar to that for mean diameter as a function of age (Figure 8) but naturally the threshold diazeters are much larger for a given age. Beyond seven days the threshold dianeter, 11ke the volume-average dianeter, ceases to decrease very rapldiy.

The significance to be attributed to the threshold diameter Is not frmediately apparent, and some additional experiment vas helpful In Its interpretation. Samples of paste vere presaured to preseures Just less than, and also slightly greater than, the pressure correupondlng to the threshold diameter. The aaples were then depreasurized, broken open, and fracture surfaces examined In an optical meroscope. The total intrusion that had taken place was alight, in either cose, compared to the total intrusion possible for the saaple at high pressures. Nevertheless, algniflcant differences vere noted in the color and in the appearance 
of the samples under the microscope. The color of the sanple Intruded to less than the threshold dameter was 11ght gray; microscople examination disclosed localized "streans" of mercury along the fractured croas-section of the interfor, but also many local reglons vere present within the aleroecope fleld with little observable evidence of penetration by mercury. In contrast, the sample presoured to just beyond the threshold value was dark gray in color; exasination under the optical microacope revealed the presence of darkened areas and droplets of exuding mercury uniformly spaced over all regions of the fracture aurface. Macrophotographs of an unintruded paste specimen and specinens intruded to fust belou and Just above the threahold diameter are given in Figure 10.

Additional Iaformation bearing on the anture of the threshold dianeter had to do with the time required to reach equilibriun In a given Inerement of intrusion of mercury. It was noted that a drastic slowing down of the rate of penetration of wercury geemed to take place while making intrusion measurements near the threshold dianeter. A series of special runs were made in which the time to reach equilibrium was noted at each pressuring step. Typical results of weh determinations are glven In Figure 12. The data ere plotted in terns of the equilibration time per unit volume Intruded, 1.e. an Inverse rate of penetration, vs, nominal diameter. Data are given for 2 day old and 318 day old pastes of both vatertcenent ratios. It is cleer that at the threahold dianeter, the rate of penetration of mercury is exceedingly slov compared to the rate both for Intrualon Into the coareer pores 
and for Intrueion Into the bulk of the pore space in pores finer than the threshold diameter.

These observations are interpreted in the follouing aanner. It is considered that the threahold diaseter represente the minfmu dianeter of pores which are geonetrically continuous throughout all regions of the hydrated cenent paste. Sone poren of dianeter larger than this are present and available to the exterfor, especially for the 0.6 pastes; but the volune of such easily avallable coarse pores is sall and they are easily intruded from the exterior of the opecinea. Pores larger than the threshold diseter, but avallable to the outside only through the continuous pore systen, are $11 \mathrm{kely}$ aloo present to some extent. As the pressure corresponding to this charncterlstic dlaneter is reached, nercury begins to flow Into new regions of the sample frow the exterior of the paste. Th1s flow presumbily follows a long, tortuous path, and since essentially all of the mercury has to flow Into the paste from new locations at or near the exterfor, the process 1s correspondingly slow. Finslly, perhaps at a preasura alighely In excess of that corresponding to the initial slowtng down, the geometrically continuous channel system leading through all meroregions of the paste 1e f11led. Further intrusion (and by far the greater portion of the pore space has yet to be intruded) comes about through a process of fllling what must be local sidechannele and pores of flner and flner damater froe mercury already in the continuous channels. This flliting of secoudary porea, constituting the bulk of the pore systea, is agaln rapid, since 
flow paths are short. Thus the pore system of cement paste is visualized as constituting a geometrical aystem analagoua in sowe respects to a Ifinely branched river systen with the relatively large porea intruded at the threahold diameter corresponding to che anfor rivers flowing through a geographical region, and the rest of the pores corresponding to local brench streane. The Latrusion process corresponds, of course, not to drainage but to a hypothetical reverse flow frou the river mouths.

The phenonenon of slow intruston at a threahold dianeter has been observed by M. M. Rfnelou of Prado Labotatorles for a large nubber of other types of porous nateriale (private cosmunication).

\section{Infleence of Kater: Cenent Racio}

Av aoted, and again in accord with all reasonable expectet1on, all of the parametere describing porosity are larger for the 0.6 vater:cement ratio pastes than for the 0.4 water:cenent rat1o pastes of the same age.

Whet appears to be of some siguificance to the writers io the fact that the paraseters, in general, are not eo very much grester for the 0.6 as coapered to the 0.4 pastea. For eatuple, the chreshold dianeters of Figure 9, the volune-average pore dlaneters of PIgare 8, and the generel appearince and location of the cunulative eurves of F1gurea 6 and 7, Iadicate that the pores of the 0.6 paste serfes are, as the pastes age, not really different in general aize range than those of the 0.4 paste, espectally after the first day. This is not at all in sceord 
with the notions of hydration formally encompased in the

Powers wodel, on the basis of which one would envision that the excess cap11lary space avaflable at all stages for the 0.6 paste should remain in very large pores commensurate in size with the original pores present at the tine of set.

General Pattern of the Pore-Size Distribution Curves

The approxinately sidlar shapes of the pore-siae distribution curves with aging do not lend support to the notion that the bydration process consists of replacing large units of eap11lary space with nore or less single elzed pores of a characteristic and very fine dianeter. Rather 1t appears to the vriters to be indicative of a general and continuing process of subdivioion of pores.

In this context, the evolution with time of the Internediate size class of pores is instructive. For example, if one exhmines the apparent content of pores between arbierary boundaries of $0.1 \mu(1000 \mathrm{~A})$ and $0.01 \mu(100 \mathrm{~A})$, one finds a gradual Increase at first, then a gradual decrease as the general porostey becomes f1ner. For the 0.6 ser1es, the apporent content of pores between these alse boundarlea $180.080 \mathrm{~cm}^{3} / 8$ at one day, Increasing to about $0.175 \mathrm{ca}^{3} / \mathrm{g}$ at 28 days, and then decreasing silghtly to about $0.160 \mathrm{ca}^{3} / \mathrm{g}$. Correnponding $\mathrm{figures}$ for the 0.4 series are $0.085 \mathrm{~cm}^{3} / 8$ at one day, Increasing to about $0.150 \mathrm{~cm}^{3} / \mathrm{g}$ at seven days, and then decreasing gradually to about $0.100 \mathrm{~cm}^{3} / \mathrm{g}$. Thus, 1t may be argued that the reduction in pore alze with age is not acconplished by replacing lerge ("capillary") 
pores with very fine ("ge1") pores without regard to Intermediate afzes, as conventional formulations would imply, but rather one of continuou aarrowing of pores as particulate bydration products are latd down. In auch a process the content of Internediatesised pores vould be expected to increase as the coerse pores are Inttially subdivided, and then gradually decrease as apaces betveea grains of bydration products grow finer aad Iner; this Is exactly vhat seess to happen.

\section{concuusions}

1. Mercury Intrualon of dried cement paste aupplies a reproducible and apparently satisfactory direct nethod for the sssesunent of pore-size distributions, provided due caution is displayed In experimental details, in insuring completeness of water removal by rigoroue drylng, and in use of a realistic contact angle value. Due regard should be paid to the poosible exdetence of 1nk-bottle pores, 1solated pores, and to the defficiency of the pore shape model.

2. Direct measurements confim the general concept that as a paste hydrates the total pore volvme decreases and a general reduction in pore sizen takes place.

3. The neasurements are in contradiction to specific aotions of the nature of cesient paste generally accepted. The content of porea f1ner than 82 A as estinated by difference betueen intruded volume and total volume ia sigaificantly less than the voluse of "ge1" pores assuned to be present on the basis of cenant sodels. The content of pores betseen $0.1 \mathrm{v}$ and $0.01 \mathrm{w}$, 
"In-between" cap1llary and gel pore sizes by current notions,

Is found to be very substantial at all ages.

4. The evidence points toward a notion that most of the volume In cenent paste is neither "cap11lary" porosity nor "gel" porosity per se, but largely consists of spaces left between particulate hydration products, perhaps supplesented by pores on apparently spongy hydration products occesionally found to be present in scanning electron meroscope observation.

5. The existence of a "threshold dianeter" for nercury intrusion In paste is noted; and its regular decrease vith age docueented. It 1e associated with very slov fntrusion and with a qual1tative difference in conpleteness of penetration of mercury to all general regions of the sample. It is concluded that the threshold diameter corresponds approximately to the minimum disater of channels that are essentially continuous through the paste at a given age.

\section{ACKNOWLEDGEMENTS}

Th1s paper is based in part on the MSCE thesis of the first named author (Purdue Dniversity, 1968) and reprenents initial results of a research project supported by the Indiana State Highway Cotalseion and the Bureau of Public Roads, v. 5 . Departmeat of Transportation. Thanks are due to $\mathrm{M}$. M. WInslov for pernission to we the patented filling device, and w. L. Dolch for technical counsel. 


\section{References}

1. Povers, T. C., "Physical Properties of Cenent Paste" Cheniatiy of Cement (Proe. 4th Int. Cof., Washington, 1960) pp 577-608.

2. Chatterj1, S. and Jeffery, J. W., "Three-dimenstonal Arrangenent of Hydratioa Products in Set Cement Pastes" llature (Lond.) Vo1. 209, ko. 5029, March 19, 1966 pp. 1233-1234.

3. Mi11s, R. H., "Collapse of Structure in Ceneat Hydrates", Paper presentad at Conference on Scanning Electron Microacopy Cambridge, Englend, July 1968.

4. Dianond, Sidney, Written Discussion on "Struetures and Fhyeical Properties of Ceaent Paste" by G. J. Verbeck and R. A. Heinuth; Written Discuesion Volume, Proc. Sth Int. Conf. on the Chenistry of Cenent, 1968, pp. 96-105.

5. Neahburn, z. W., "A Kote on a Method of Deternining the Diotribution of Pore S1zes in a Porous Material", Proceedinge, listionel Acadeny of Science Vo1. 7, 1921, p. 115.

6. Kenba11, C., "On the Surface Tension of Nercury", Trans. Faraday Soc., Vol. 42 1946, pp. 526-537.

7. Hicholas, M. E., Joyner, P. A., Tesses, B. M., and OLsen, M. D., "The Effects of Various Gases and Vapors on the Surface Tension of Kereury" J. Physical Chesistry Vo1. 65, 1961, pp. 1373-1375.

8. Powere, T. C., "The Nonevaporable Water Content of Hardened Portland Cesant: Pasta", ASTi Bulletin No. 158, May 1949, pp. 68-76.

9. Adan, N. K. "The Physics and Chemistry of Surfacen" Dover Publications, Inc., New York, 1968, pp. 185-186.

10. Copeland, L. E. and Hayes, John C., "The Deternination of HonEvaporable Watex In Hardened Portland Cement Paste", ASTM Bulletin No. 194 , Dec. 1953 , p. 9.

11. Copeland, L. B. and Bragg, R. H., "The Hydrates of Magneatum Perchlorate", Journal of Physical Chemiatry, Vol. 58, 1954, pp. 1075-1081.

12. Povers, I. C., "The Physical Structure of Portlaad Cement Paste" in "The Chealstry of Cenents", ㅂ. F. W. Teylor, ed. 1964, Meadeals Press, London, pp. 391-416. 


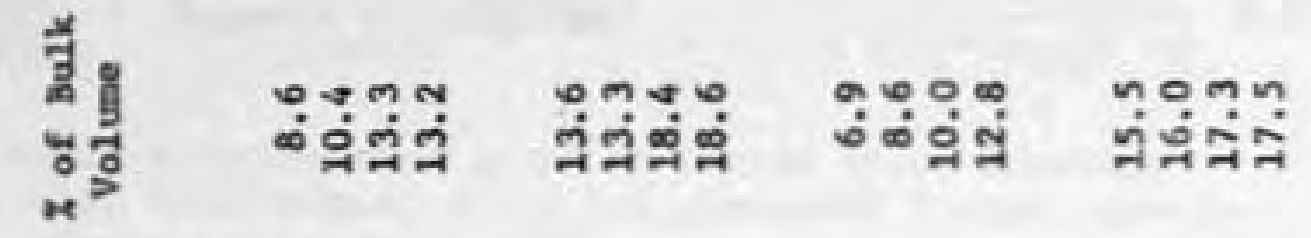

$$
\begin{aligned}
& \text { M! }
\end{aligned}
$$

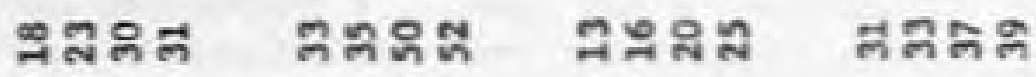

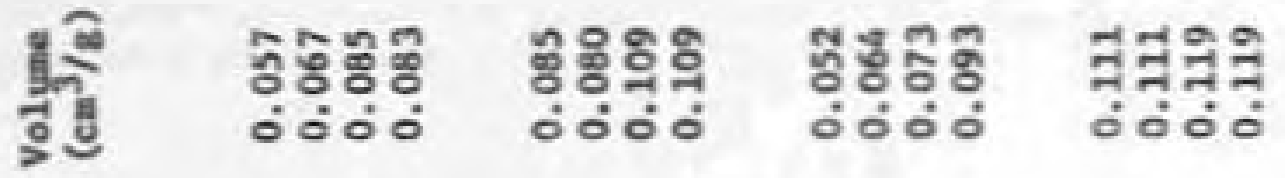

$$
\begin{aligned}
& \text { เั }
\end{aligned}
$$

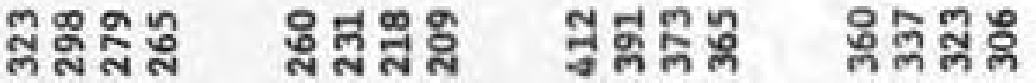

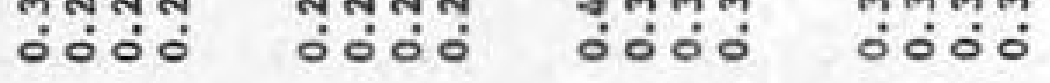

$$
\begin{aligned}
& \text { 녕 }
\end{aligned}
$$

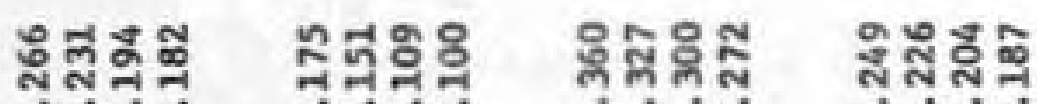

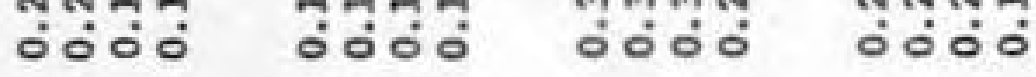

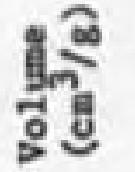




\section{Legends for FIgures}

Iigure 1 Scaning electron aferograph of cenent paste fracture curface, water:cenent rat10 0.6 , hydrated 7 days, showing sub-microa pore space.

PHgure 2 Scanning electroa nierogrsph of cenent paste fracture surface, water:cenent ratio 0.6 , hydrated 7 days, shoving reticular spongey area between lime crystals.

Pigure 3 Mercury 1ntrusion deta for ceant psste disk wed for measuresents of contact angle.

Tigure 4 Influence of easple drying procedure on mesured pore size distribution. Cesent psate has vatericement rat10 of 0.4 , hydrated 158 days.

Figure 5 Pore sise dietribution messurenante 11luatrating reveralbility of drying effect. Cement paste has vater:cenent ratio of 0.4 , hydrated 158 daye.

71gure 6 Pore sise distributions of water:cenent ratio 0.6 cement: pastes hydrated for varlous ages.

Pigure 7 Pore sise distributions of water: cement retio 0.4 cenent: pastea hydrated for varions ages.

Pigure 8 Mean pore dlameters as functions of age for two water: cement ratioe.

Figure 9 "Threshold dianeters" as functlong of sige for two vater: cenent ratios.

Figure 10 Fracture surfacea of cenent paste. Top; unintruded. Center; Intruded to diasater just larger than "threshold dlaseter". Botton; intruded to diametor fust gmalier shan "threshold dianeter".

74gure 11 Inverse rate of nercury intrusloa as a function of pare diameter for anture ceaent pastes. 


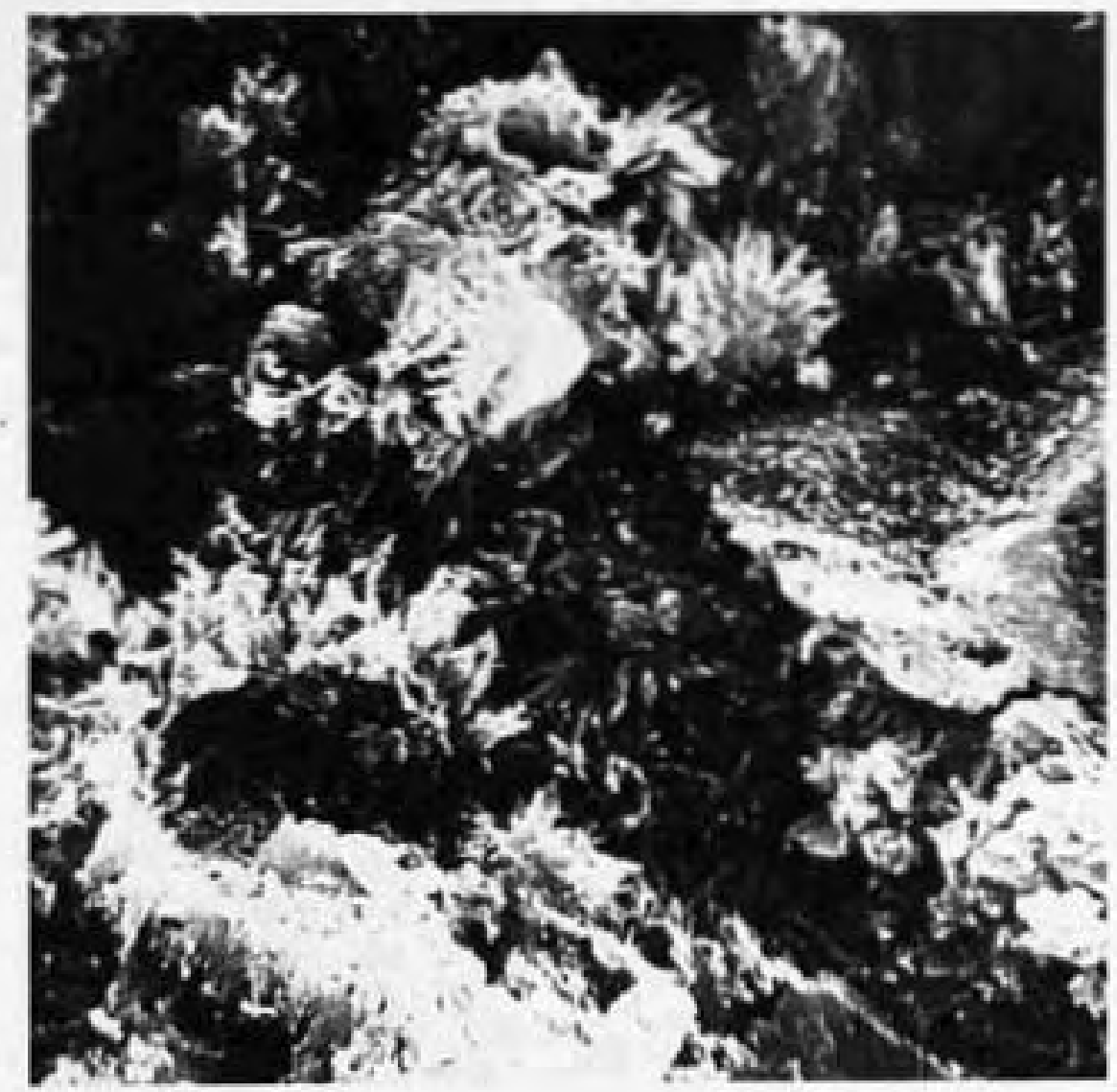




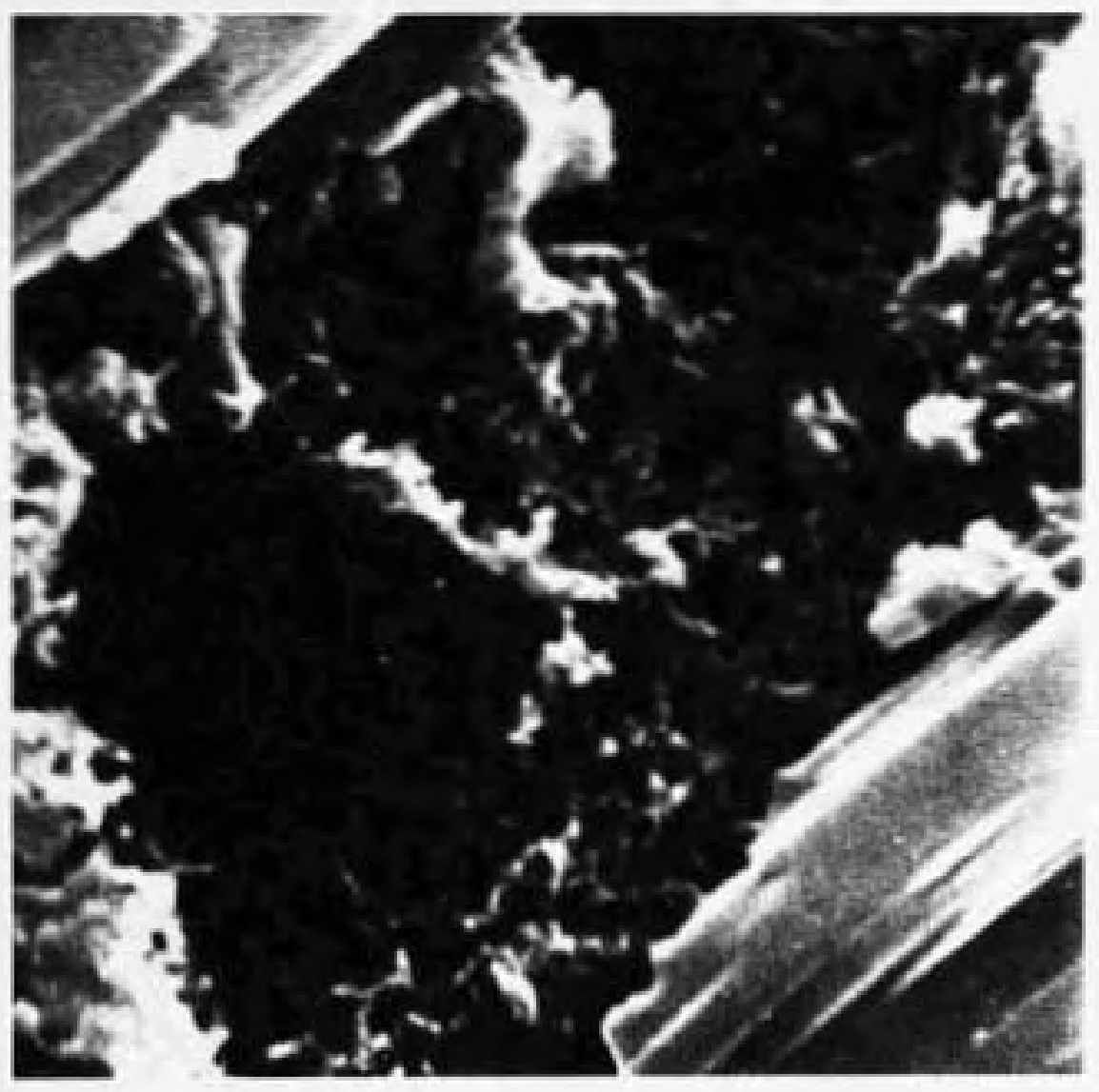




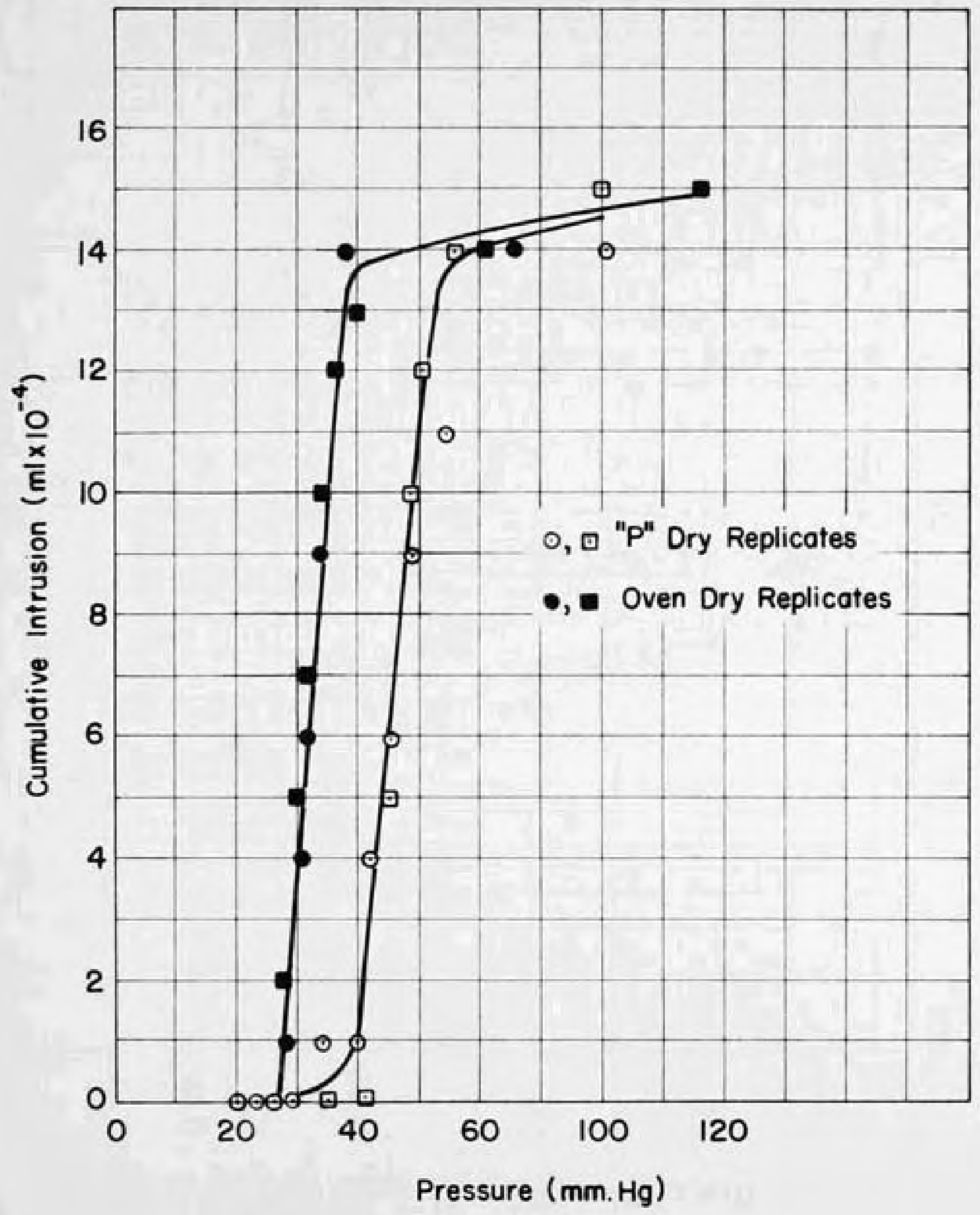




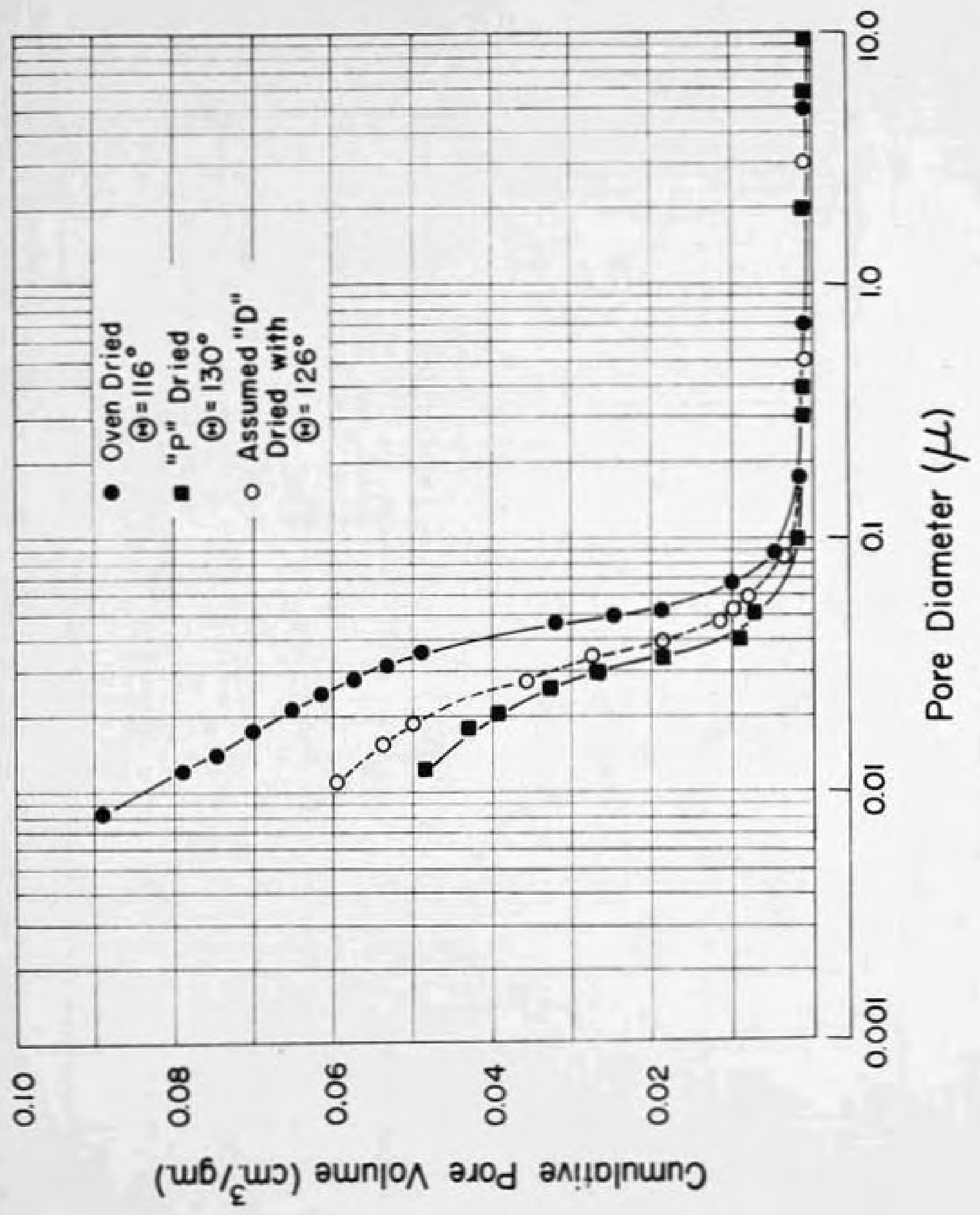




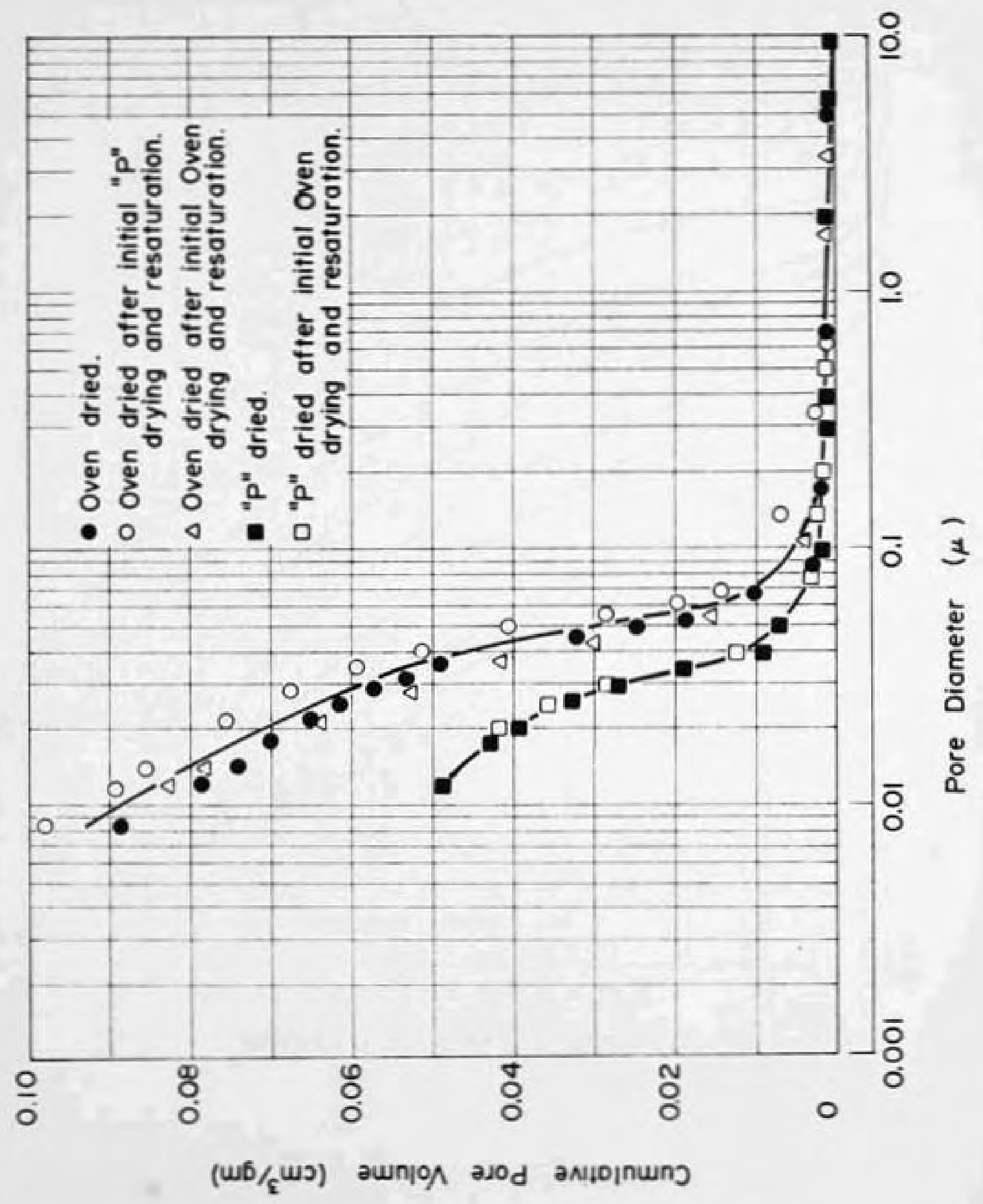




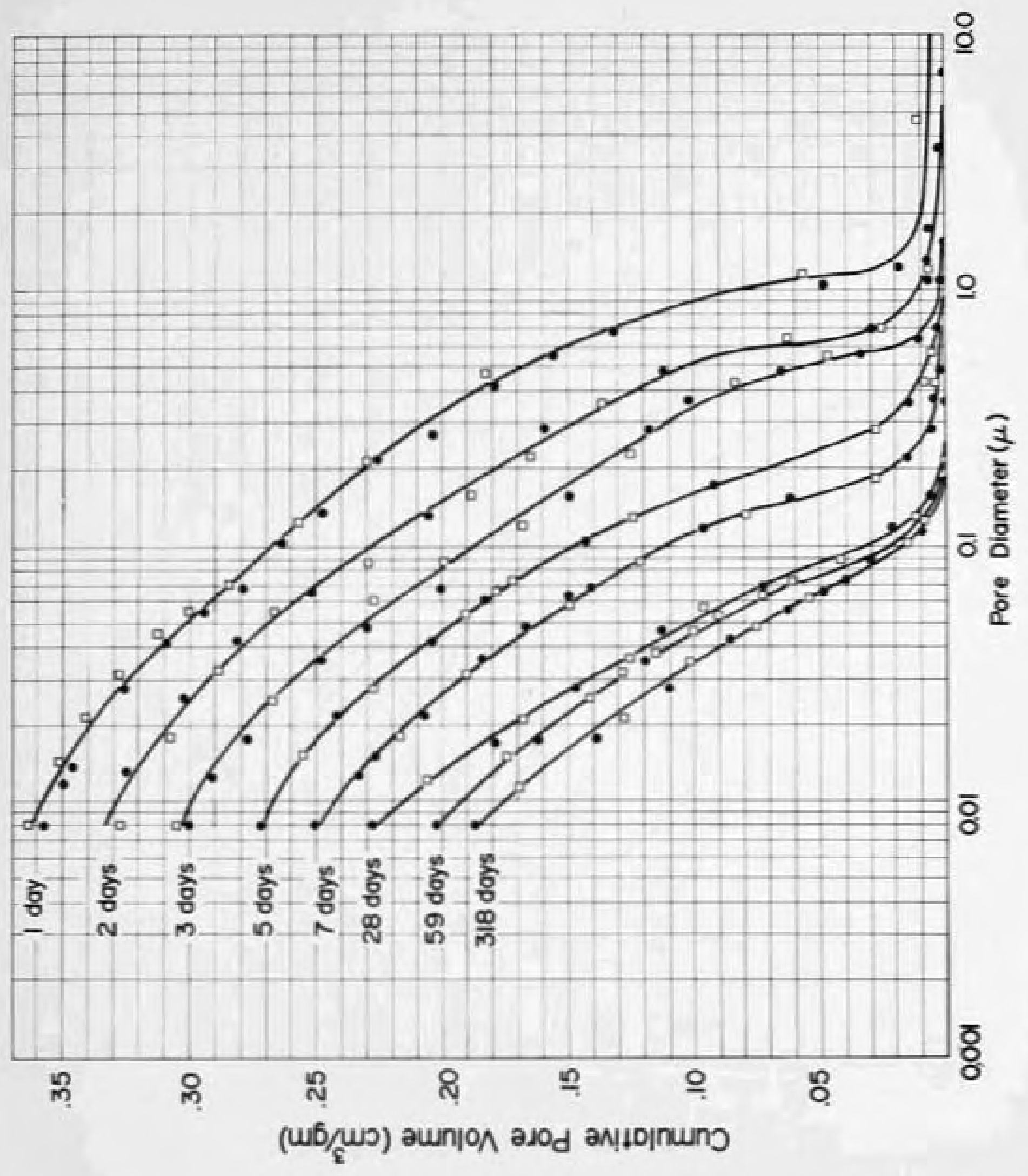




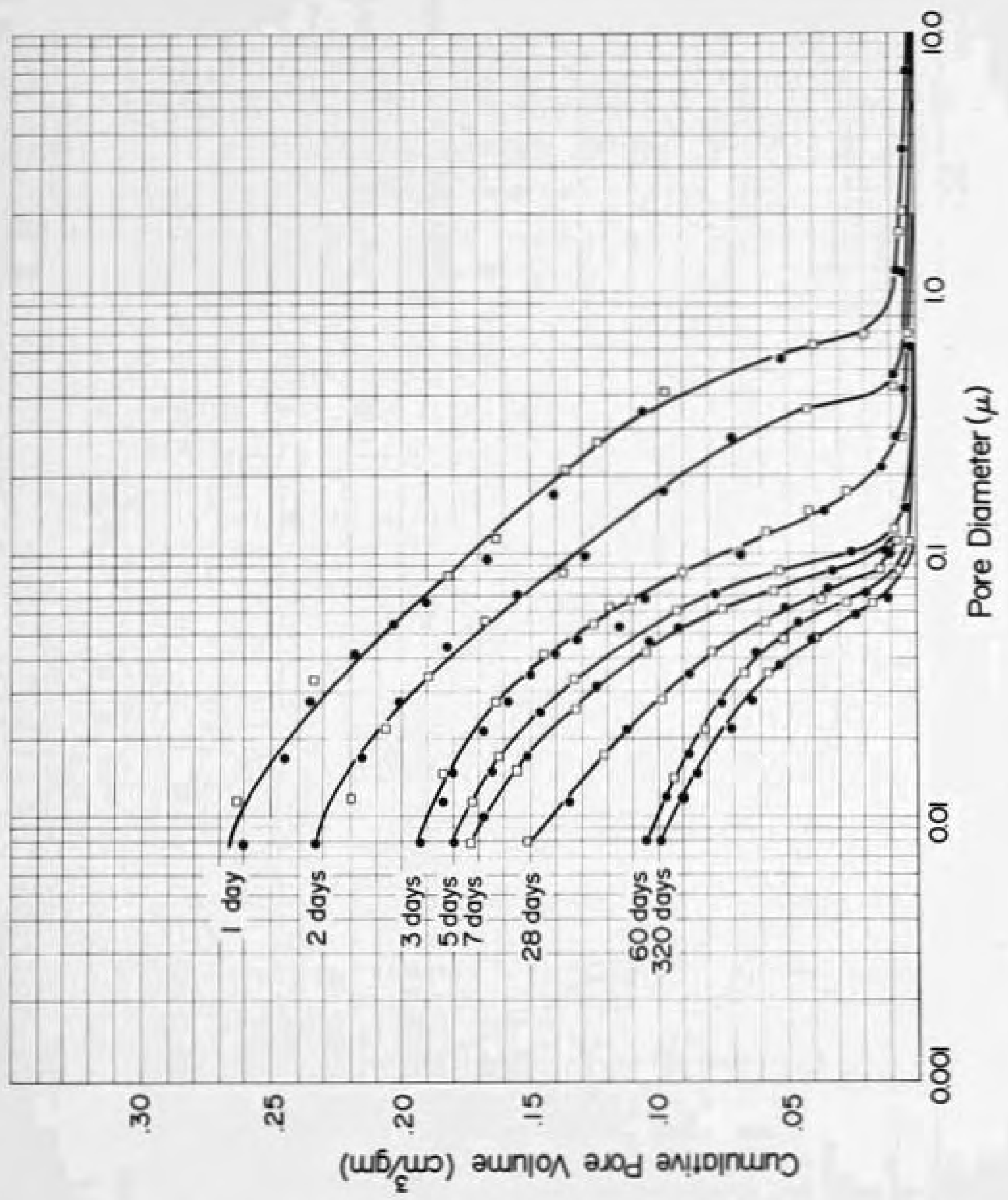




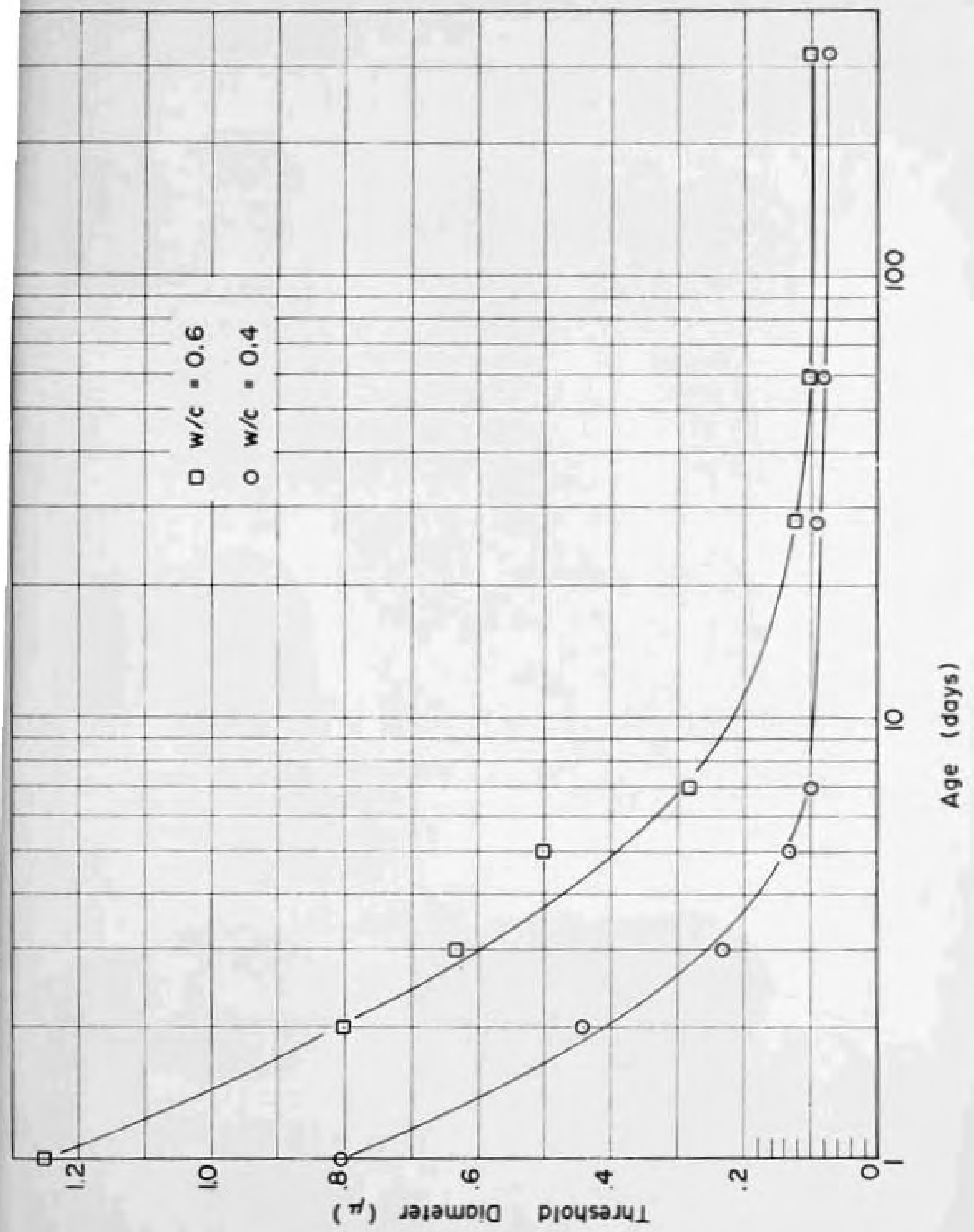



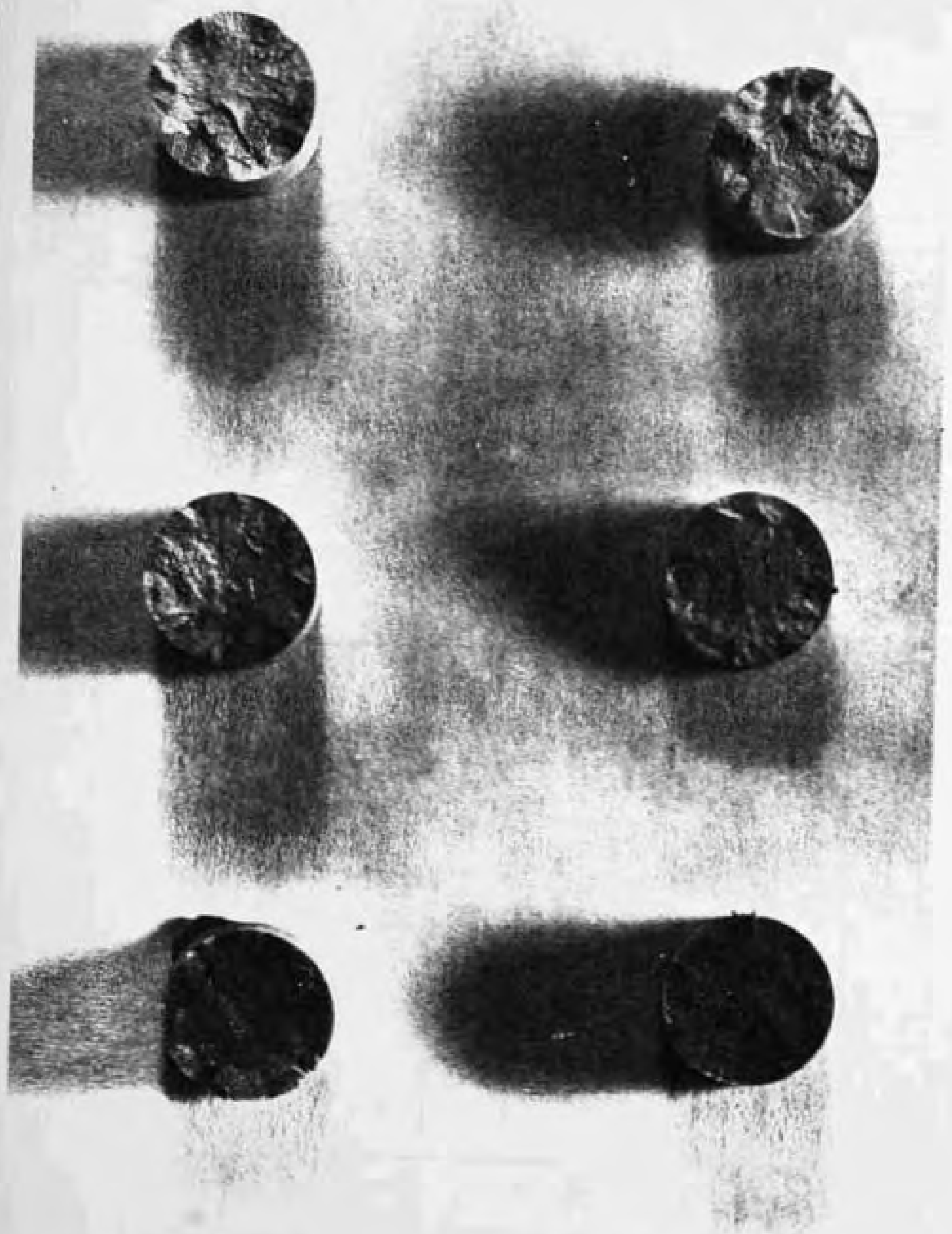


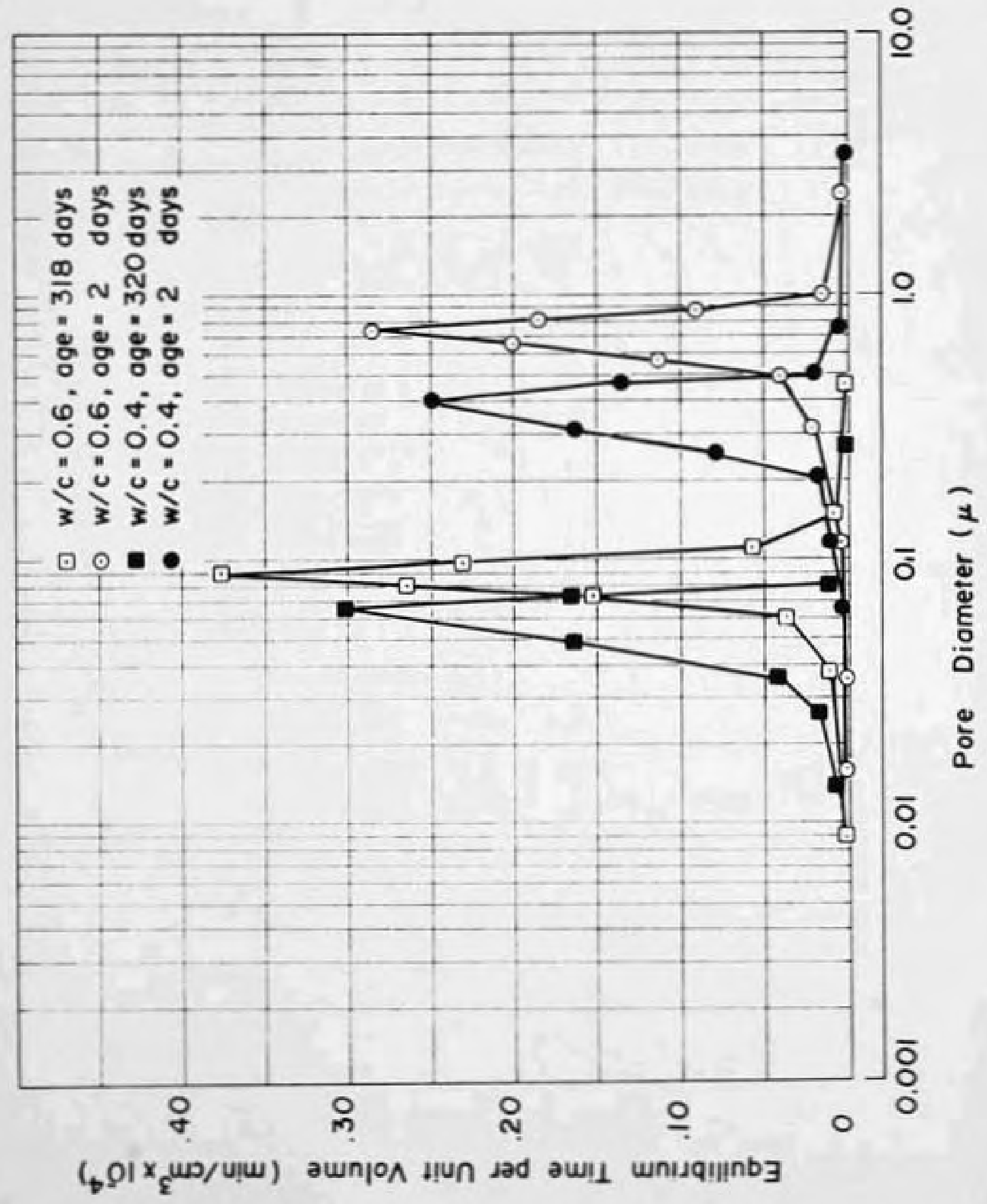

